Article

\title{
Association between the Microsatellite Ap243, AC117 and SV185 Polymorphisms and Nosema Disease in the Dark Forest Bee Apis mellifera mellifera
}

\author{
Nadezhda V. Ostroverkhova ${ }^{1,2}$ \\ 1 Invertebrate Zoology Department, Biology Institute, National Research Tomsk State University, \\ 36 Lenina Avenue, 634050 Tomsk, Russia; nvostrov@mail.ru; Tel.: +7-3822-529-461 \\ 2 Department of Biology and Genetics, Siberian State Medical University, 2 Moskovsky Trakt, \\ 634055 Tomsk, Russia
}

Citation: Ostroverkhova, N.V.

Association between the

Microsatellite Ap243, AC117 and

SV185 Polymorphisms and Nosema Disease in the Dark Forest Bee Apis mellifera mellifera. Vet. Sci. 2021, 8, 2. https://doi.org/10.3390/vetsci 8010002

Received: 9 December 2020 Accepted: 24 December 2020 Published: 29 December 2020

Publisher's Note: MDPI stays neutral with regard to jurisdictional clai$\mathrm{ms}$ in published maps and institutional affiliations.

Copyright: (C) 2020 by the author. Licensee MDPI, Basel, Switzerland. This article is an open access article distributed under the terms and conditions of the Creative Commons Attribution (CC BY) license (https:// creativecommons.org/licenses/by/ $4.0 /)$.

\begin{abstract}
The microsporidian Nosema parasites, primarily Nosema ceranae, remain critical threats to the health of the honey bee Apis mellifera. One promising intervention approach is the breeding of Nosema-resistant honey bee colonies using molecular technologies, for example marker-assisted selection (MAS). For this, specific genetic markers used in bee selection should be developed. The objective of the paper is to search for associations between some microsatellite markers and Nosema disease in a dark forest bee Apis mellifera mellifera. For the dark forest bee, the most promising molecular genetic markers for determining resistance to nosemosis are microsatellite loci AC117, Ap243 and SV185, the alleles of which ("177", "263" and "269", respectively) were associated with a low level of Nosema infection. This article is the first associative study aimed at finding DNA loci of resistance to nosemosis in the dark forest bee. Nevertheless, microsatellite markers identified can be used to predict the risk of developing the Nosema disease.
\end{abstract}

Keywords: Nosema disease; dark forest bee; Apis mellifera mellifera; microsatellite loci; association

\section{Introduction}

In the last few decades, negative processes such as massive losses of bee colonies and hybridization have been observed in honey bee populations worldwide. The honey bee colony losses, called colony collapse disorder (CCD), as a result of reduced adaptation of honey bees to environmental factors, pose a threat to beekeeping worldwide [1,2]. It has been suggested that CCD can be caused by many causes, including various diseases such as nosemosis, environmental pollution, exposure to pesticides, weather and agricultural and beekeeping practices [3-5]. On the one hand, in order to avoid a catastrophic population decline from pests and diseases, it is necessary to maintain a high level of genetic diversity in honey bee populations [6,7]. On the other hand, molecular technologies, for example marker-assisted selection (MAS) can be used to identify bee colonies carrying specific traits of interest (e.g., resistance to pathogens and parasites, gentleness and high honey productivity) or the lack of undesirable traits (e.g., aggression and swarming) [8-11]. Marker-assisted selection is a new technology in beekeeping, and no specific genetic markers that could be used in bee breeding have been proposed [12,13].

The search for informative DNA loci/genes associated with economically useful and other traits (associative mapping) is highly relevant. The preferred strategy is to genotype a high number of genetic markers in linkage or association studies in order to identify genomic regions and discover the causative genes [14]. The identification of genetic markers associated with the phenotype can also immediately be used to selectively breed colonies that are more resistant [15].

Currently, quantitative trait loci (QTLs) associated with queen fertility [16,17], resistance to chalkbrood [18,19] and varroosis [20,21], and various types of behavior [22-24] 
have been identified. For example, hygiene behavior, which is a social behavior helps control various diseases of the offspring such as varroosis [25-27]. Varroosis is one of the most devastating diseases of the brood caused by the parasitic mite Varroa destructor [28-30]. Hygiene behavior has been shown to provide significant resistance against the Varroa mite $[13,30]$. QTL studies of Varroa resistance behavior in honey bees have identified over 20 suggestive QTLs in different genomic regions [14,20-22,31].

Like varroosis, nosemosis is also one of the most dangerous diseases [32-34], but the study of associations between molecular genetic markers and nosemosis is rare [35,36].

Nosemosis is a serious disease in adult honey bees caused by microsporidia, which are obligate intracellular eukaryotic parasites [37]. Nosema parasites multiply and develop within the host-cell cytoplasm causing extensive and even total destruction of the midgut epithelial layer $[38,39]$.

In European honey bees, two species of microsporidia, Nosema apis and Nosema ceranae, have been described. N. apis Zander, 1909 [40] is an evolutionarily old parasite of the honey bee A. mellifera. The parasite causing type A nosemosis is moderately virulent, and bee colonies are able to resist disease under favorable environmental conditions [41-43]. N. ceranae Fries et al., 1996 [44], responsible for type C nosemosis, is a relatively new parasite for the A. mellifera [38,44-46]. This parasite was originally described in an Asian bee Apis cerana in the late 20th century [44]. Since 2006, it has been found in honey bee A. mellifera populations around the world $[38,41-43,45,47-54]$. Compared to N. apis, N. ceranae is considered a more virulent parasite, and in some countries, such as the Mediterranean countries, it is associated with the bee colony losses [32,55-58].

Using microsatellite markers, four QTLs associated with low spore load were revealed in a Danish selected Nosema-resistant honey bees line [35]. These Buckfast honey bee colonies have been selectively bred for the absence of Nosema over decades, resulting in a breeding line that is tolerant toward Nosema $[59,60]$. Unlike pure race breeding, the Buckfast breeding system mixes different stocks to establish a hybrid bee with desired characteristics. The Buckfast contains heritage from mainly A. m. ligustica and A. m. mellifera and from other subspecies. Since the Buckfast bee is a hybrid bee, the expression of its notable characteristics can vary greatly within the stock [61].

It is assumed that the honey bee subspecies (lines and colonies) differ in their resistance to disease, which may be determined by social immunity including hygienic and other types of behavior $[13,15,30,62-70]$. For example, in A. mellifera, hygienic and grooming behaviors are expressed more highly in Africanized honey bees than in European ones. Perhaps this explains the higher resistance of Africanized bees to $V$. destructor compared to European bees [71].

Although no significant effect of $N$. ceranae infections on hygienic behavior was detected [72], it is clear that natural resistance of honey bees to Nosema depends on many factors and the genetic variants of honey bees can play a relevant role. The purpose of this study was to identify associations between genetic variants of some microsatellite loci and Nosema infection/disease resistance in the dark forest bee Apis mellifera mellifera.

\section{Materials and Methods}

\subsection{Bee Samples}

In the present study, samples of a dark forest bee Apis mellifera mellifera from Siberian populations (longitude $81^{\circ} 29^{\prime}-92^{\circ} 08^{\prime} \mathrm{E}$ and latitude $50^{\circ} 44^{\prime}-65^{\circ} 47^{\prime} \mathrm{N}$ ) were examined. The dark forest bee is a native bee that was introduced to Siberia about 230 years ago and has adapted well to the local climate and plant communities. In Siberia, the bee population is an artificial population; wintering of bees is controlled by people [73]. Honey bees were collected from 12 apiaries between the end of May 2016 and August of the same year. A total of 226 workers from twenty-eight bee colonies (from 8 to 10 bees from each bee colony) were examined.

For the diagnosis and detection of Nosema infection, the oldest honey bees (forager bees) were collected outside the entrance of hive, because they have the greatest infection 
and the highest proportion of infected bees [39]. Bee samples were stored in a freezer at $-20^{\circ} \mathrm{C}$ until further processing.

\subsection{Study Design}

The present research has conducted in several stages. At the first stage of the study, the presence of Nosema spp. in honey bees was investigated using both light microscopy and polymerase chain reaction (PCR).

At the second stage of the study, the genetic diversity of honey bees with different degrees of Nosema infestation was examined using polymorphic microsatellite loci. Earlier, the genetic diversity of local dark forest bees (Siberian population) was studied using a complex of microsatellite loci and identified polymorphic microsatellite loci [74]. In this study, 23 polymorphic microsatellite loci were used to search for genetic markers of Nosema disease resistance in honey bees.

Finally, the associations of polymorphic variants of microsatellite loci studied with nosemosis were analyzed using the odds ratio method (OR).

\subsection{Experimental Procedures}

To carry out individual analysis of the bees, for each sample, the bee's midgut was isolated and divided in two. One part of the midgut was used for light microscopy. For this, the midgut was ground in $0.5 \mathrm{~mL}$ of sterile, distilled water and the number of Nosema spores was counted using a Zeiss Axio Lab.1 light microscope.

DNA was extracted from another part of the midgut using a DNA purification kit, PureLink ${ }^{\mathrm{TM}}$ Mini (Invitrogen, Carlsbad, CA, USA) according to the manufacturer's protocol. PCR was performed using a thermal MyCycler T100 (BioRad, Foster City, CA, USA).

For the diagnosis of nosemosis, duplex-PCR was used [42]. The primer sequences used to amplify the $321 \mathrm{bp}$ fragment corresponding to the $16 \mathrm{~S}$ ribosomal gene of $N$. apis were 321APIS-FOR 5' -GGGGGCATGTCTTTGACGTACTATGTA- $3^{\prime}$ and 321APIS-REV 5'GGGGGGCGTTTAAAATGTGAAACAACTATG-3'. The primer sequences utilized to amplify the $218 \mathrm{bp}$ fragment corresponding to the $16 \mathrm{~S}$ ribosomal gene of $N$. ceranae were 218MITOC-FOR 5'-CGGCGACGATGTGATATGAAAATATTAA-3' ${ }^{\prime}$ and 218MITOC-REV $5^{\prime}$-CCCGGTCATTCTCAAACAAAAAACCG-3' [42]. PCR was performed in a reaction volume of $20 \mu \mathrm{L}$ containing 5-10 ng of template DNA, $1 \times$ PCR buffer, $200 \mu \mathrm{M}$ of each dNTP, $1.5 \mathrm{mM} \mathrm{MgCl}_{2}, 0.2 \mu \mathrm{M}$ of each primer and $1 \mathrm{U}$ Taq polymerase (Fermentas, Thermo Fisher Scientific, Chelmsford, MA, USA). The routine consisted of an initial denaturation step at $94{ }^{\circ} \mathrm{C}$ for $2 \mathrm{~min}$, followed by 35 cycles of $94{ }^{\circ} \mathrm{C}$ for $30 \mathrm{~s}, 58^{\circ} \mathrm{C}$ for $30 \mathrm{~s}$ and $72{ }^{\circ} \mathrm{C}$ for $1 \mathrm{~min}$, and a final extension step at $72{ }^{\circ} \mathrm{C}$ for $5 \mathrm{~min}$. PCR products were analyzed on $1.5 \%$ agarose gels. Gels were stained with ethidium bromide and visualized using UV illumination (Gel Doc XR+, BioRad, Foster City, CA, USA). For each PCR, positive control (reference $N$. apis and $N$. ceranae DNA extracts as template) was used. Negative control (ddH2O) was also included in each run of PCR amplification to detect possible contamination.

The variability of 23 polymorphic microsatellite loci (Ap066, K0457B, K1168, A007, A008, A028, A043, Ap049, Ap007, AC117, 6339, Ap068, Ap243, SV220, SV167, SV185, Ap226, H110, A024, AT139, A056, Ap249, and A113) was examined. When choosing loci, some factors such as a high level of polymorphism, maximum chromosomal coverage (the studied loci are located on 13 out of 16 honey bee chromosomes), and data from publications on DNA markers associated with bee resistance to diseases were considered. PCR was performed using specific fluorescence-labeled primers according to Solignac et al. [75]. The reactions were performed in $20 \mu \mathrm{L}$ of a solution containing 5-10 ng DNA template, $0.4 \mu \mathrm{M}$ of each primer, $60 \mu \mathrm{M}$ of each dNTP, $1-2.5 \mathrm{mM} \mathrm{MgCl}_{2}$ and $1 \times \mathrm{PCR}$ buffer and $1 \mathrm{U}$ of Taq polymerase (Fermentas, Thermo Fisher Scientific, Chelmsford, MA, USA). After a denaturing step of $3 \mathrm{~min}$ at $94^{\circ} \mathrm{C}$, samples were processed through 35 cycles consisting of $30 \mathrm{~s}$ at $94{ }^{\circ} \mathrm{C}, 30 \mathrm{~s}$ at $55-60^{\circ} \mathrm{C}$ and $30 \mathrm{~s}$ at $72{ }^{\circ} \mathrm{C}$. The final elongation step was $10 \mathrm{~min}$ at $72{ }^{\circ} \mathrm{C}$ [75]. Amplification products were analyzed with ABI Prism 3730 
Genetic Analyzer and GeneMapper Software (Applied Biosystems, Inc., Foster City, CA, USA) in the collective center Medical Genomics (Research Institute of Medical Genetics, Tomsk National Research Medical Center, Russian Academy of Sciences, Moscow, Russia). Two microliters of PCR products were mixed with GeneScan500-ROX size standards (Applied Biosystems, Inc.) and deionized formamide. Samples were run according to the manufacturer's recommendations.

\subsection{Estimation of the Nosemosis Level}

According to PCR, most of the bees examined were coinfected with two Nosema species, $N$. apis and N. ceranae. In this regard, we considered the general infestation of honey bees with microsporidia, without division into Nosema species. A light microscope using $400 \times$ magnification was used for counting Nosema spores in macerated bee preparations.

Honey bees were divided into the following groups, uninfected (Nosema-negative) and Nosema-infected (Nosema-positive). Since our study did not require a high degree of precision, we used an arbitrary infection scale and divided the Nosema-positive bee group into two variants, Nosema-positive low and Nosema-positive high. Nosema-positive low bees were with a small amount of microsporidial spores on microscopic analysis (less than 100 spores in the field of view of the microscope). Nosema-positive high bees were with a significant number of microsporidial spores detected by microscopic analysis (more than 500 spores in the field of view of the microscope). An intermediate variant of the bee infection (100-500 Nosema spores in the field of view of the microscope) was not identified. In total, three groups of bees were formed: Nosema-negative, Nosema-positive low and Nosema-positive high.

\subsection{Statistical Analysis}

The genotypes obtained for each of the honey bee were used to estimate population parameters. The allelic and genotypic observed frequencies by Hardy-Weinberg equilibrium $(\mathrm{HWE})$, the number of alleles, observed $(\mathrm{Ho})$ and expected $(\mathrm{He})$ heterozygosity were estimated employing the GENEPOP v.4.1 package [76]. To assess genetic diversity, for each infectious category, the observed and expected heterozygosity for each locus were compared using a Student's test. Comparison of allele and genotype frequencies between bee samples that differed in Nosema infestation was performed using the chi-square test. In the case of a small number of one of the comparison classes, the chi-square test with Yates correction was used.

To assess the association of polymorphic variants of the microsatellite loci studied with Nosema infection in bees, the odds ratio (OR) and $95 \%$ confidence interval (95\% CI) corresponding to the $p$-value was calculated [77]. The association of the genetic marker with the tested trait was determined by the OR value when the differences in the allele frequency between the compared groups reached the level of statistical significance, $p<0.05$. If the OR $>1$, the assumption about the association of the analyzed genetic variant (allele/genotype) with the studied pathology is considered (increased chance of developing disease). When the $\mathrm{OR}<1$, a protective role of the corresponding genetic variant (allele/genotype) is assumed.

\section{Results}

\subsection{Genetic Diversity of the A. m. mellifera Honey Bees in Siberia on the Microsatellite Loci}

Honey bees with different degrees of Nosema infestation were genotyped using $23 \mathrm{mi}-$ crosatellite markers. When comparing the distribution of allele frequencies between three groups of the A. m. mellifera bees (Nosema-negative, Nosema-positive low and Nosemapositive high), several loci (AC117, A113, Ap243, A024, A007, Ap049 and SV185) were identified that are promising for further analysis. The parameters of genetic diversity of these loci, such as the frequencies of alleles and genotypes, expected heterozygosity and observed heterozygosity, are presented in Table 1. 
Table 1. Genotype and allele frequencies and heterozygosity at 7 microsatellite loci in the dark forest bees with varying degrees of Nosema infection.

\begin{tabular}{|c|c|c|c|c|c|c|c|c|}
\hline \multirow{3}{*}{ Locus } & \multirow{3}{*}{ Genotype } & \multirow{3}{*}{ Allele } & \multicolumn{6}{|c|}{ Infection Categories of Honey Bees } \\
\hline & & & \multicolumn{2}{|c|}{ Nosema-Negative } & \multicolumn{2}{|c|}{ Nosema-Positive Low } & \multicolumn{2}{|c|}{ Nosema-Positive High } \\
\hline & & & Genotype & Allele & Genotype & Allele & Genotype & Allele \\
\hline \multirow{9}{*}{ AC117 } & $173-173$ & 173 & 0.037 & $0.074 \pm 0.036$ & 0.024 & $0.079 \pm 0.017$ & \multirow{4}{*}{0.115} & $0.057 \pm 0.021$ \\
\hline & $173-181$ & 177 & 0.074 & $0.148 \pm 0.048$ & 0.110 & $0.075 \pm 0.017$ & & $0.025 \pm 0.014$ \\
\hline & $177-177$ & 181 & 0.037 & $0.296 \pm 0.062$ & 0.008 & $0.260 \pm 0.028$ & & $0.533 \pm 0.045$ \\
\hline & $177-181$ & 185 & & $0.482 \pm 0.068$ & 0.039 & $0.587 \pm 0.031$ & & $0.385 \pm 0.044$ \\
\hline & $177-185$ & & \multicolumn{2}{|l|}{$\begin{array}{l}0.222 \\
0.259\end{array}$} & \multicolumn{2}{|l|}{0.094} & \\
\hline & \multicolumn{2}{|l|}{$181-181$} & 0.259 & & \multirow{2}{*}{\multicolumn{2}{|c|}{$\begin{array}{l}0.142 \\
0.087\end{array}$}} & \multicolumn{2}{|l|}{0.475} \\
\hline & & & & & & & \multirow{2}{*}{\multicolumn{2}{|c|}{0.361}} \\
\hline & \multicolumn{2}{|l|}{$185-185$} & 0.370 & & 0.496 & & & \\
\hline & \multicolumn{2}{|c|}{$\mathrm{Ho} / \mathrm{He}$} & $0.296 \pm 0.08$ & $\begin{array}{l}* * / 0.653 \pm 0.040 \\
27\end{array}$ & \multicolumn{2}{|c|}{$0.331 \pm 0.042 * * / 0.577 \pm 0.025$} & \multicolumn{2}{|c|}{$0.164 \pm 0.047^{* *} / 0.564 \pm 0.025$} \\
\hline & $210-218$ & 210 & & & 0.016 & $0.008 \pm 0.006$ & & \\
\hline & $212-212$ & 212 & & $0.107 \pm 0.041$ & 0.063 & $0.152 \pm 0.023$ & 0.016 & $0.063 \pm 0.021$ \\
\hline & $212-214$ & 214 & 0.036 & $0.018 \pm 0.018$ & 0.008 & $0.008 \pm 0.006$ & & \\
\hline & $212-218$ & 218 & 0.143 & $0.518 \pm 0.067$ & 0.125 & $0.598 \pm 0.031$ & 0.094 & $0.719 \pm 0.040$ \\
\hline & $212-220$ & 220 & 0.036 & $0.339 \pm 0.063$ & 0.023 & $0.207 \pm 0.025$ & & $0.219 \pm 0.037$ \\
\hline & $212-222$ & 222 & & & 0.008 & $0.008 \pm 0.006$ & & \\
\hline & $212-226$ & 226 & & & 0.016 & $0.020 \pm 0.009$ & & \\
\hline & $214-226$ & 228 & & $0.018 \pm 0.018$ & 0.008 & & & \\
\hline A113 & $218-218$ & & 0.286 & & 0.438 & & 0.609 & \\
\hline & $218-220$ & & 0.321 & & 0.172 & & 0.125 & \\
\hline & $218-222$ & & & & 0.008 & & & \\
\hline & $220-220$ & & 0.143 & & 0.109 & & 0.156 & \\
\hline & $220-228$ & & 0.036 & & & & & \\
\hline & $226-226$ & & & & 0.008 & & & \\
\hline & $\begin{array}{r}\mathrm{Ho} / \\
\mathrm{N}\end{array}$ & & $0.571 \pm 0$. & $\begin{array}{l}94 / 0.605 \pm 0.041 \\
28\end{array}$ & $0.383 \pm 0.04$ & $\begin{array}{l}* * / 0.577 \pm 0.027 \\
128\end{array}$ & $0.219 \pm 0.05$ & $\begin{array}{l}* / 0.432 \pm 0.043 \\
64\end{array}$ \\
\hline & $253-260$ & 253 & 0.043 & $0.022 \pm 0.022$ & & & 0.074 & $0.037 \pm 0.026$ \\
\hline & $256-256$ & 256 & 0.305 & $0.413 \pm 0.073$ & 0.284 & $0.419 \pm 0.035$ & 0.519 & $0.593 \pm 0.067$ \\
\hline & $256-263$ & 260 & 0.218 & $0.109 \pm 0.046$ & 0.233 & $0.111 \pm 0.022$ & 0.074 & $0.167 \pm 0.051$ \\
\hline & $256-266$ & 263 & & $0.239 \pm 0.063$ & & $0.283 \pm 0.032$ & 0.074 & $0.056 \pm 0.031$ \\
\hline & $256-269$ & 266 & & $0.022 \pm 0.022$ & 0.030 & $0.010 \pm 0.007$ & & $0.037 \pm 0.026$ \\
\hline & $256-272$ & 269 & & $0.109 \pm 0.046$ & 0.010 & $0.096 \pm 0.021$ & & $0.037 \pm 0.026$ \\
\hline & $260-260$ & 272 & 0.043 & $0.022 \pm 0.022$ & 0.081 & $0.035 \pm 0.013$ & 0.111 & $0.056 \pm 0.031$ \\
\hline & $260-263$ & 275 & 0.043 & $0.065 \pm 0.036$ & 0.010 & $0.046 \pm 0.015$ & & $0.019 \pm 0.018$ \\
\hline & $260-266$ & & 0.043 & & 0.020 & & & \\
\hline 4243 & $260-269$ & & & & 0.030 & & 0.037 & \\
\hline Ap243 & $263-263$ & & 0.043 & & 0.132 & & & \\
\hline & $263-269$ & & 0.043 & & 0.030 & & & \\
\hline & $263-272$ & & 0.087 & & 0.010 & & 0.037 & \\
\hline & $263-275$ & & & & 0.020 & & & \\
\hline & $269-269$ & & 0.043 & & 0.020 & & & \\
\hline & $269-272$ & & & & 0.020 & & 0.037 & \\
\hline & $269-275$ & & 0.087 & & 0.040 & & & \\
\hline & $272-275$ & & & & 0.030 & & 0.037 & \\
\hline & $\begin{array}{r}\mathrm{Ho} / \\
\mathrm{N}\end{array}$ & & $0.565 \pm 0.1$ & $\begin{array}{l}3 / 0.743 \pm 0.043 \\
23\end{array}$ & $0.485 \pm 0.05$ & $\begin{array}{l}* * / 0.719 \pm 0.020 \\
99\end{array}$ & $0.370 \pm 0.09$ & $\begin{array}{l}3 * / 0.610 \pm 0.067 \\
27\end{array}$ \\
\hline
\end{tabular}


Table 1. Cont.

\begin{tabular}{|c|c|c|c|c|c|c|c|c|}
\hline \multirow{3}{*}{ Locus } & \multirow{3}{*}{ Genotype } & \multirow{3}{*}{ Allele } & \multicolumn{6}{|c|}{ Infection Categories of Honey Bees } \\
\hline & & & \multicolumn{2}{|c|}{ Nosema-Negative } & \multicolumn{2}{|c|}{ Nosema-Positive Low } & \multicolumn{2}{|c|}{ Nosema-Positive High } \\
\hline & & & Genotype & Allele & Genotype & Allele & Genotype & Allele \\
\hline \multirow{9}{*}{ A024 } & $92-92$ & 92 & 0.500 & \multirow[t]{2}{*}{$0.712 \pm 0.063$} & 0.446 & $0.654 \pm 0.030$ & 0.313 & \multirow[t]{2}{*}{$0.578 \pm 0.044$} \\
\hline & $92-100$ & 96 & 0.231 & & 0.177 & $0.008 \pm 0.005$ & 0.219 & \\
\hline & $92-106$ & 100 & 0.192 & \multirow{2}{*}{$0.154 \pm 0.050$} & 0.238 & $0.181 \pm 0.024$ & 0.313 & \multirow{2}{*}{$0.266 \pm 0.039$} \\
\hline & $96-96$ & 102 & & & 0.008 & $0.008 \pm 0.005$ & & \\
\hline & $100-100$ & 106 & 0.038 & \multirow[t]{2}{*}{$0.135 \pm 0.047$} & 0.077 & $0.150 \pm 0.022$ & 0.156 & \multirow{2}{*}{$0.156 \pm 0.032$} \\
\hline & \multicolumn{2}{|l|}{$100-102$} & & & 0.015 & & & \\
\hline & \multicolumn{2}{|l|}{$100-106$} & & 0.015 & & & \\
\hline & \multicolumn{2}{|l|}{ 106-106 } & \multicolumn{2}{|l|}{0.038} & \multicolumn{2}{|l|}{0.023} & \multirow{2}{*}{\multicolumn{2}{|c|}{$\begin{array}{c}0.531 \pm 0.062 / 0.571 \pm 0.032 \\
64\end{array}$}} \\
\hline & $\begin{array}{r}\mathrm{Ho} / \\
\mathrm{N}\end{array}$ & & $0.423 \pm 0$. & $\begin{array}{l}7 / 0.452 \pm 0.070 \\
26\end{array}$ & $0.446 \pm 0.0$ & $\begin{array}{l}4 / 0.517 \pm 0.029 \\
130\end{array}$ & & \\
\hline \multirow{6}{*}{ A007 } & $104-108$ & 104 & \multirow[t]{2}{*}{0.185} & $0.093 \pm 0.039$ & 0.224 & $0.121 \pm 0.021$ & \multirow[t]{2}{*}{0.364} & $0.182 \pm 0.041$ \\
\hline & $104-113$ & 108 & & $0.815 \pm 0.053$ & 0.017 & $0.797 \pm 0.026$ & & $0.818 \pm 0.041$ \\
\hline & 108-108 & 113 & 0.704 & $0.093 \pm 0.039$ & 0.655 & $0.082 \pm 0.018$ & 0.636 & \\
\hline & $108-113$ & & 0.037 & & 0.060 & & & \\
\hline & $113-113$ & & 0.074 & & 0.043 & & & \\
\hline & $\begin{array}{r}\mathrm{Ho} / \\
\mathrm{N}\end{array}$ & & $0.222 \pm 0$. & $\begin{array}{l}0 / 0.319 \pm 0.075 \\
27\end{array}$ & $0.302 \pm 0.0$ & $\begin{array}{l}3 / 0.343 \pm 0.036 \\
116\end{array}$ & $0.364 \pm 0$. & $\begin{array}{l}3 / 0.298 \pm 0.052 \\
44\end{array}$ \\
\hline & $120-120$ & 120 & 0.036 & $0.161 \pm 0.049$ & 0.017 & $0.121 \pm 0.021$ & & $0.057 \pm 0.022$ \\
\hline & $120-127$ & 127 & 0.250 & $0.714 \pm 0.060$ & 0.200 & $0.646 \pm 0.031$ & 0.113 & $0.745 \pm 0.042$ \\
\hline & $120-130$ & 130 & & $0.054 \pm 0.030$ & 0.008 & $0.175 \pm 0.025$ & & $0.085 \pm 0.027$ \\
\hline & $127-127$ & 139 & 0.536 & $0.071 \pm 0.034$ & 0.425 & $0.046 \pm 0.014$ & 0.585 & $0.085 \pm 0.027$ \\
\hline & $127-130$ & 152 & 0.036 & & 0.192 & $0.013 \pm 0.007$ & 0.094 & $0.028 \pm 0.016$ \\
\hline & $127-139$ & & 0.071 & & 0.050 & & 0.113 & \\
\hline An049 & $130-130$ & & 0.036 & & 0.067 & & 0.019 & \\
\hline Apu49 & 130-139 & & & & & & 0.019 & \\
\hline & 130-152 & & & & 0.017 & & 0.019 & \\
\hline & 139-139 & & 0.036 & & 0.017 & & 0.019 & \\
\hline & 139-152 & & & & 0.008 & & & \\
\hline & $152-152$ & & & & & & 0.019 & \\
\hline & $\begin{array}{r}\mathrm{Ho} / \\
\mathrm{N}\end{array}$ & & $0.357 \pm 0$. & $\begin{array}{l}1 / 0.456 \pm 0.071 \\
28\end{array}$ & $0.475 \pm 0.0$ & $\begin{array}{l}6 / 0.535 \pm 0.032 \\
120\end{array}$ & $0.359 \pm 0 .($ & $\begin{array}{l}6 / 0.426 \pm 0.057 \\
53\end{array}$ \\
\hline & $253-253$ & 253 & & & 0.009 & $0.022 \pm 0.010$ & & \\
\hline & $253-272$ & 263 & & $0.241 \pm 0.058$ & 0.027 & $0.313 \pm 0.031$ & & $0.385 \pm 0.050$ \\
\hline & $263-263$ & 266 & 0.037 & $0.093 \pm 0.039$ & 0.134 & $0.094 \pm 0.020$ & 0.146 & $0.146 \pm 0.036$ \\
\hline & $263-266$ & 269 & & $0.667 \pm 0.064$ & 0.045 & $0.549 \pm 0.033$ & 0.125 & $0.469 \pm 0.051$ \\
\hline & $263-269$ & 272 & 0.407 & & 0.304 & $0.023 \pm 0.010$ & 0.354 & \\
\hline & $263-272$ & & & & 0.009 & & & \\
\hline SV185 & $266-266$ & & 0.074 & & 0.045 & & & \\
\hline & $266-269$ & & 0.037 & & 0.054 & & 0.167 & \\
\hline & $269-269$ & & 0.444 & & 0.366 & & 0.208 & \\
\hline & $269-272$ & & & & 0.009 & & & \\
\hline & $\begin{array}{r}\text { Ho } / \\
N\end{array}$ & & $0.444 \pm 0$. & $\begin{array}{l}6 / 0.489 \pm 0.061 \\
27\end{array}$ & $0.446 \pm 0.04$ & $\begin{array}{l}* / 0.591 \pm 0.023 \\
112\end{array}$ & $0.646 \pm 0$. & $\begin{array}{l}9 / 0.611 \pm 0.023 \\
48\end{array}$ \\
\hline
\end{tabular}

N-the number of bee samples analyzed within each infection category; Ho-observed heterozygosity; He-expected heterozygosity according to Hardy-Weinberg equilibrium. In the table, the values of allele frequencies and parameters of heterozygosity with a standard error are given. Statistically significant differences in the observed heterozygosity from the expected heterozygosity are marked with $\left({ }^{*}\right)$ $(* p<0.05, * * p 0.001)$.

All microsatellite loci studied were polymorphic: the minimum number of alleles was found for locus A007 ( 3 alleles), and the maximum number of alleles was for loci A113 and Ap243 (8 alleles); the average number of alleles per locus was 5 (Table 1).

Some studied loci differed in the variability in honey bees of different infectious categories (uninfected and Nosema-infected bees). For example, for the Ap243 locus, the frequency of the predominant allele "256" differs in bees of two Nosema-positive groups, 
Nosema-positive low and Nosema-positive high bees $(\mathrm{t}=2.30 ; p<0.05)$. Interestingly, the frequency of the other allele ("263") of the Ap243 locus was also statistically significantly different between uninfected (Nosema-negative) and significantly Nosema-infected (Nosemapositive high) bees $(\mathrm{t}=2.61 ; p<0.05)$ and between two Nosema-positive groups $(\mathrm{t}=5.10$; $p<0.001$ ). In addition, the frequency of alleles " 177 " and "181" of the AC117 locus differs between Nosema-negative and Nosema-positive high bees $(t=2.46 ; p<0.05$ and $t=3.09$; $p<0.05$, respectively), and between bees of two Nosema-positive groups $(\mathrm{t}=2.27 ; p<0.05$ and $\mathrm{t}=5.15 ; p<0.01$, respectively).

An assessment of the heterozygosity of most of the studied loci (except for loci A007 and SV185 in Nosema-positive high bees) revealed lower values of the observed heterozygosity (Ho) compared with the expected heterozygosity (He) (Table 1). A statistically significant level of differences between the values of the observed and expected heterozygosity is shown for the following loci: A113 $(\mathrm{t}=3.82, p<0.001$ and $\mathrm{t}=3.16, p<0.05)$, Ap243 $(\mathrm{t}=4.35, p<0.001$ and $\mathrm{t}=2.09, p<0.05)$ in Nosema-positive low and high bees, respectively; SV185 $(t=2.77, p<0.05)$ in Nosema-positive low bees; AC117 $(t>3.69, p<0.001)$ in all infection categories of bees.

Thus, the analysis of the variability of 23 microsatellite loci in the A. m. mellifera honey bees allowed us to identify the most promising loci for searching for associations of DNA markers with the Nosema disease.

\subsection{Comparative Characteristics of the Genetic Diversity of A. m. mellifera Bees from Different Infectious Categories}

The heterogeneity of bee groups differing in the degree of Nosema infection was evaluated. To do this, statistically significant differences between the bee groups in allele frequencies of microsatellite loci were determined.

For some microsatellite loci (AC117, A113, Ap243 and Ap049), differences in the distribution of allele frequencies (in total) between infectious categories of bees are shown. Mainly, differences were found between infected bees (Nosema-positive low and Nosemapositive high bees): locus AC117 $\left(\chi^{2}=44.61, \mathrm{df}=7, p<0.01\right)$; locus A113 $\left(\chi^{2}=12.76\right.$, $\mathrm{df}=5, p<0.05)$; locus Ap243 $\left(\chi^{2}=19.77, \mathrm{df}=7, p<0.01\right)$ and locus Ap049 $\left(\chi^{2}=14.70\right.$, $\mathrm{df}=7, p<0.05)$. In addition, for the AC117 locus, differences were revealed between uninfected and Nosema-positive high bees $\left(\chi^{2}=19.84, \mathrm{df}=7, p<0.01\right)$. No statistically significant differences were found between the groups of uninfected bees and Nosemapositive low bees.

For the locus AC117, the alleles "177", "181" and "185" make the largest contribution. The "177" allele is most often found in uninfected bees than Nosema-positive high bees $\left(\chi^{2}=9.59, \mathrm{df}=1, p<0.01\right)$. On the contrary, the "181" allele is more typical for Nosemapositive high bees than for uninfected $\left(\chi^{2}=8.66, \mathrm{df}=1, p<0.01\right)$ and Nosema-positive low $\left(\chi^{2}=26.56, \mathrm{df}=1, p<0.01\right)$ bees. For the "185" allele, differences were found between the two groups of infected bees $\left(\chi^{2}=14.17, \mathrm{df}=1, p<0.01\right)$.

For the locus A113, the allele "218" defines the differences between Nosema-negative and Nosema-positive high bees $\left(\chi^{2}=6.81, \mathrm{df}=1, p<0.01\right)$. In addition, significant differences were also found between Nosema infected (low and high) bees on the frequency of the alleles " 218 " $\left(\chi^{2}=6.12, \mathrm{df}=1, p<0.05\right)$ and " 212 " $\left(\chi^{2}=6.60, \mathrm{df}=1, p<0.01\right)$.

For the locus Ap243, the frequencies of two alleles "256" and "263" were significantly different in the groups of infected bees $\left(\chi^{2}=5.80, \mathrm{df}=1, p<0.05\right.$ and $\chi^{2}=12.45, \mathrm{df}=1$, $p<0.01$, respectively). Allele " 256 " prevailed in Nosema infected high bees, while allele "263" was more common in Nosema infected low bees (Table 1). The allele "263" also determined differences between groups of uninfected and Nosema-positive high bees $\left(\chi^{2}=6.98, \mathrm{df}=1\right.$, $p<0.01)$.

For the locus Ap049, alleles "127" and "130" determine the differences between groups of infected bees $\left(\chi^{2}=4.00, \mathrm{df}=1, p<0.05\right.$ and $\chi^{2}=5.12, \mathrm{df}=1, p<0.05$, respectively), while allele "120" was between uninfected and Nosema-positive high bees $\left(\chi^{2}=4.69, \mathrm{df}=1\right.$, $p<0.05)$. 
Despite the fact that no significant differences were found in the distribution of all alleles (in total) of loci A007, A024 and SV185, there existed differences for some alleles of these loci. For example, allele "269" of the SV185 locus determined the differences between groups of Nosema-uninfected and Nosema-positive high bees $\left(\chi^{2}=5.65, \mathrm{df}=1, p<0.05\right)$.

3.3. Assessment of Associations of Genetic Markers with Nosema Infection/Resistance in the Dark Forest Bee A. m. mellifera

In order to search for alleles, possibly associated with Nosema disease in the dark forest bees (A. m. mellifera), the odds ratio, OR, was calculated (Table 2).

For loci AC117, A113, Ap243, A024, A007, Ap049 and SV185, statistically significant differences in allele and/or genotype frequencies between the compared groups (infection categories) were shown. However, according to OR calculations, only some genetic variants of these loci showed associations with Nosema infestation. Based on the calculated OR, it can be concluded that alleles "177" of the AC117 locus, "263" of the Ap243 locus and " 269 " of the SV185 locus have protective properties (that is, they reduce the risk of Nosema infection).

Table 2. Comparative analysis of the frequency of potentially significant genetic variants in the formation of nosemosis resistance in the dark forest bee $A$. m. mellifera.

\begin{tabular}{|c|c|c|c|c|c|}
\hline \multirow[b]{2}{*}{ Locus } & \multirow[b]{2}{*}{$\begin{array}{c}\text { Compared } \\
\text { Alleles/Genotypes }\end{array}$} & \multirow[b]{2}{*}{ Parameters } & \multicolumn{3}{|c|}{ Compared Honey Bee Groups } \\
\hline & & & $\begin{array}{c}\text { Nosema-Negative- } \\
\text { Nosema-Positive } \\
\text { Low }\end{array}$ & $\begin{array}{c}\text { Nosema-Negative- } \\
\text { Nosema-Positive } \\
\text { High }\end{array}$ & $\begin{array}{c}\text { Nosema-Positive } \\
\text { Low-Nosema-Positive } \\
\text { High }\end{array}$ \\
\hline \multirow{6}{*}{ AC117 } & \multirow{3}{*}{ Allele 177 vs. others } & OR & 0.46 & 0.16 & 0.35 \\
\hline & & $95 \% \mathrm{CI}$ & $0.18-1.24$ & $0.04-0.58$ & $0.11-1.13$ \\
\hline & & $\chi^{2} / p$ & $2.15 / 0.17$ & $7.76 / 0.005$ & $2.92 / 0.09$ \\
\hline & \multirow{3}{*}{$\begin{array}{l}\text { Homo- and } \\
\text { heterozygous } \\
\text { genotypes with an } \\
\text { allele } 177 \text { vs. others }\end{array}$} & OR & 0.47 & 0.16 & 0.35 \\
\hline & & $95 \% \mathrm{CI}$ & $0.16-1.43$ & $0.04-0.64$ & $0.11-1.16$ \\
\hline & & $\chi^{2} / p$ & $1.48 / 0.22$ & $6.25 / 0.01$ & $2.69 / 0.10$ \\
\hline \multirow{3}{*}{ A113 } & \multirow{3}{*}{ Allele 218 vs. others } & OR & 1.38 & 2.38 & 1.72 \\
\hline & & $95 \% \mathrm{CI}$ & $0.74-2.57$ & $1.18-4.80$ & $1.04-1.39$ \\
\hline & & $\chi^{2} / p$ & $0.90 / 0.34$ & $6.12 / 0.01$ & $4.91 / 0.03$ \\
\hline \multirow{6}{*}{ Ap243 } & \multirow{3}{*}{ Allele 263 vs. others } & OR & 1.25 & 0.21 & 0.17 \\
\hline & & $95 \% \mathrm{CI}$ & $0.27-2.83$ & $0.06-0.75$ & $0.06-0.53$ \\
\hline & & $\chi^{2} / p$ & $0.17 / 0.68$ & $5.51 / 0.02$ & $10.99 / 0.0009$ \\
\hline & \multirow{3}{*}{$\begin{array}{l}\text { Homo- and } \\
\text { heterozygous } \\
\text { genotypes with an } \\
\text { allele } 263 \text { vs. others }\end{array}$} & OR & 1.00 & 0.18 & 0.19 \\
\hline & & $95 \% \mathrm{CI}$ & $0.37-2.74$ & $0.05-0.73$ & $0.06-0.51$ \\
\hline & & $\chi^{2} / p$ & $0.05 / 0.82$ & $5.19 / 0.02$ & $8.22 / 0.004$ \\
\hline \multirow{6}{*}{ A024 } & \multirow{3}{*}{ Allele 92 vs. others } & OR & 0.77 & 0.56 & 0.73 \\
\hline & & $95 \% \mathrm{CI}$ & $0.38-1.53$ & $0.26-1.17$ & $0.46-1.15$ \\
\hline & & $\chi^{2} / p$ & $0.41 / 0.52$ & $2.25 / 0.13$ & $1.80 / 0.18$ \\
\hline & \multirow{3}{*}{ Allele 100 vs. others } & OR & 1.21 & 1.99 & 1.64 \\
\hline & & $95 \% \mathrm{CI}$ & $0.51-3.00$ & $0.80-5.10$ & $0.96-2.16$ \\
\hline & & $\chi^{2} / p$ & $0.07 / 0.79$ & $2.00 / 0.16$ & $3.24 / 0.07$ \\
\hline
\end{tabular}


Table 2. Cont.

\begin{tabular}{|c|c|c|c|c|c|}
\hline \multirow[b]{2}{*}{ Locus } & \multirow[b]{2}{*}{$\begin{array}{c}\text { Compared } \\
\text { Alleles/Genotypes }\end{array}$} & \multirow[b]{2}{*}{ Parameters } & \multicolumn{3}{|c|}{ Compared Honey Bee Groups } \\
\hline & & & $\begin{array}{c}\text { Nosema-Negative- } \\
\text { Nosema-Positive } \\
\text { Low }\end{array}$ & $\begin{array}{c}\text { Nosema-Negative- } \\
\text { Nosema-Positive } \\
\text { High }\end{array}$ & $\begin{array}{c}\text { Nosema-Positive } \\
\text { Low-Nosema-Positive } \\
\text { High }\end{array}$ \\
\hline \multirow{3}{*}{ A007 } & \multirow{3}{*}{ Allele 104 vs. others } & OR & 1.35 & 2.18 & 1.62 \\
\hline & & $95 \%$ CI & $0.46-4.19$ & $0.69-7.32$ & $0.78-3.32$ \\
\hline & & $\chi^{2} / p$ & $0.12 / 0.73$ & $1.47 / 0.23$ & $1.53 / 0.22$ \\
\hline \multirow{3}{*}{ Ap049 } & \multirow{3}{*}{ Allele 120 vs. others } & OR & 0.72 & 0.31 & 0.44 \\
\hline & & $95 \% \mathrm{CI}$ & $0.30-1.76$ & $0.09-1.04$ & $0.16-1.15$ \\
\hline & & $\chi^{2} / p$ & $0.34 / 0.56$ & $3.57 / 0.06$ & $2.67 / 0.10$ \\
\hline \multirow{3}{*}{ SV185 } & \multirow{3}{*}{ Allele 269 vs. others } & OR & 0.61 & 0.44 & 0.72 \\
\hline & & $95 \% \mathrm{CI}$ & $0.31-1.18$ & $0.21-0.93$ & $0.44-1.20$ \\
\hline & & $\chi^{2} / p$ & $2.00 / 0.16$ & $4.68 / 0.03$ & $1.43 / 0.23$ \\
\hline
\end{tabular}

OR—odds ratio, $95 \%$ CI-limits of the $95 \%$ confidence interval, $\chi^{2} / p-\chi^{2}$ test and its level of significance, $\mathrm{df}=1$. Alleles for which the level of statistical significance on OR has been reached are indicated in bold.

It is worth pointing out that the frequency of homo- and heterozygous genotypes with an allele "177" of the AC117 locus decreased in the sequence: uninfected bees (25.9\% of Nosema-negative individuals) were weakly infected (14.1\% of Nosema-positive low bees) and significantly infected (4.9\% of Nosema-positive high individuals) (Table 1). Between the extreme compared groups of bees (Nosema-negative and Nosema-positive high) differences in the frequency of individuals with genotypes having this allele reach the level of statistical significance $\left(\chi^{2}=16.61, \mathrm{df}=2, p<0.01\right)$. For the Ap243 locus, the frequency of genotypes with the " 263 " allele in Nosema-positive high bees (11.1\%) differed significantly from both uninfected bees $\left(43.3 \% ; \chi^{2}=13.45, \mathrm{df}=6, p<0.05\right)$ and Nosema-positive low individuals $\left(43.5 \% ; \chi^{2}=18.86, \mathrm{df}=7, p<0.01\right)$ (Table 1$)$. For the SV185 locus, there were no differences between the compared groups at the genotype level $(p>0.05)$. In addition, the results obtained suggest that the "218" allele of the A113 locus is associated with an increased risk of nosemosis in A. m. mellifera bees (no differences were recorded at the genotype level).

\section{Discussion}

The genetic diversity of the A. m. mellifera bees, differing in the degree of Nosema infection, was investigated, and a search for associations between genetic variants of microsatellite loci and Nosema disease was carried out. The present results show that some alleles of microsatellite loci are associated with nosemosis in the A. m. mellifera bees living in the Siberian region. For example, alleles "177" of the AC117 locus, "263" of the Ap243 locus and "269" of the SV185 locus reduce the risk of Nosema infection.

This study found associations of genetic markers with Nosema infection/disease resistance in honey bees and was an exploratory study. Therefore, it is necessary to understand whether the results obtained were random or reflected some general biological regularities. Possible solutions to this issue are expanding the bee samples and/or analyzing different bee subspecies and studying them in terms of the importance of microsatellite loci in determining resistance to nosemosis.

Previously, the associations of some microsatellite loci in the Apis mellifera carpathica bees were analyzed by us together with T. Kireeva (Tomsk State University, our unpublished data) [78]. Interestingly, for the Ap243 locus, statistically significant differences were also shown between uninfected and Nosema-infected A. m. carpathica bees $\left(\chi^{2}=22.93, \mathrm{df}=7\right.$, $p<0.01)$. Alleles " 253 " and " 256 " determine the differences between groups of uninfected and Nosema-infected bees $\left(\chi^{2}=9.69, \mathrm{df}=1, p<0.01\right.$ and $\chi^{2}=7.03, \mathrm{df}=1, p<0.01$, respectively). Based on the calculated OR, it can be concluded that allele " 256 " of the Ap243 locus has protective properties (OR $=0.29,95 \% \mathrm{CI}-0.10-0.84, \chi^{2} / p-6.87 / 0.0088$, 
$\chi^{2}$-Yeats $/ p$-5.57/0.0182), while allele "253", on the contrary, increased the risk of Nosema infection (OR $=3.57,95 \%$ CI-1.53-8.40, $\chi^{2} / p-11.10 / 0.00086, \chi^{2}$-Yeats $\left./ p-9.77 / 0.0018\right)$.

Thus, among the investigated microsatellite loci, the Ap243 locus located on chromosome 1 (group 1.1) was shared for two bee subspecies (A. m. mellifera and A. m. carpathica) and is probably associated with the incidence/resistance to nosemosis. However, in these subspecies, different alleles associated with Nosema disease were identified. For A. m. mellifera bees, allele "263" probably reduced the risk of infection with nosemosis (protective role), and statistically significant differences were also found at the genotype level in bees of different groups (Nosema-positive high bees differed from uninfected and Nosema-positive low bees). In A. m. carpathica bees, statistically significant differences were found for two alleles ("256" and "253") between uninfected bees and Nosema-infected individuals, and the allele " 256 " is likely to have a protective meaning, while the allele " 253 ", on the contrary, is associated with a disease.

In addition, the A024 locus is also of interest for studying its association with nosemosis. Despite the fact that in the A. m. mellifera bees, no allele of the A024 locus showed association with Nosema disease (Table 2), in the A. m. carpathica bees, the allele "90" probably determines the resistance to nosemosis $\left(\mathrm{OR}=0.09,95 \% \mathrm{CI}-0.04-0.023, \chi^{2} / p\right.$ 39.94/0.0000000, $\chi^{2}$-Yeats $\left./ p-37.93 / 0.0000000\right)$.

It should be noted that for two bee subspecies, various microsatellite loci and alleles associated with the Nosema incidence/resistance have been identified, which may be determined by the different resistance of bee subspecies to nosemosis and/or by different habitats of bees (geographic, natural, climatic and nutritional conditions) [58,79-82]. Perhaps, in addition to the subspecies-specific features to Nosema resistance, the revealed differences can be determined by the structure of the chromosomal region where the QTL is located. For example, not this locus itself, but another, which is in linkage disequilibrium with it, may be involved in the determination of resistance to nosemosis, i.e., different alleles are in the same linkage group with a favorable variant in different bee subspecies.

The few hygienic behavior-related studies focused on finding quantitative trait loci controlling Varroa resistance hygienic behavior of honey bees have also identified different chromosomal regions related to hygienic behavior and reduced mite reproduction [14,20-22,31]. QTL studies of Varroa resistance behavior have identified over 20 suggestive chromosome regions associated with linkage groups $2,3,4,5,6,7,9,10,13$, 15, 16 and 22. For example, using RAPD markers, Lapidge et al. (2002) found seven suggestive QTLs controlling hygienic behavior of honey bees [22]. Using microsatellite loci, Oxley et al. (2010) identified three significant and three suggestive QTLs that influence a honey bee worker's propensity to engage in hygienic behavior [31] whereas Behrens et al. (2011) identified three QTLs controlling reduced mite reproduction in the Swiss Varroa mite tolerant honey bee lineage [20]. In the QTL study presented by Spötter et al., six SNPs showed significant genome-wide associations with hygienic behavior against Varroa at the genotype level [14].

It is worth pointing out that the presented studies did not identify the same (common) QTLs associated with hygienic behavior of honey bees. For example, Oxley et al. (2010) and Behrens et al. (2011) identified two QTLs for the trait in different regions of chromosome 9 [20,31]. Additionally, Tsuruda et al. (2012) also reported one major QTL on chromosome 9, but in a different region, for hygienic behavior against Varroa using a small-scale SNP-Chip [21]. Thus, the identified genomic regions related to hygienic behavior are different, which can be explained by different bee materials (freeze-killed brood, brood and worker bees), different research methods used and DNA markers analyzed (RAPD markers, microsatellite loci or SNP), different genetic maps (map based on RAPD or microsatellite markers). Finally, the use of different bee subspecies can significantly affect the research outcome. For example, in QTL studies presented by Oxley et al. (2010) and Spötter et al. (2016), QTLs were identified in the same chromosomes (chromosomes 2 and 5), but at different ends of the chromosome [14,31]. It is assumed that different bee material used in these studies contributed to the differences in the genomic regions identified [14]. On the 
one hand, a freeze-killed brood instead of brood that was artificially infested with Varroa was used in Oxley et al.'s research [31]. On the other hand, two different bee subspecies (Apis mellifera ligustica and Apis mellifera carnica) have been investigated [14].

A comparison between the QTLs involved in N. ceranae infection tolerance according to Huang et al.'s study [35] and our own trait-associated regions found no agreement. So, four QTLs located on chromosomes 3, 10,6 and 14 were significantly associated with low Nosema spore load, explaining $20.4 \%$ of total spore load variance in the selected Nosema-resistant Danish honey bee strain. The significant QTL on chromosome 14 explains 7.7\% of the total variance and may be responsible for the resistance to nosemosis in the selected Danish honey bee. A candidate gene Aubergine $(A u b)$ within this QTL region was significantly more overexpressed in drones with a low spore load than in those with a high spore load [35].

From the data presented, in the dark forest bee, microsatellite loci Ap243 (chromosome 1), SV185 (chromosome 5) and AC117 (chromosome 12) are associated with resistance to nosemosis. It is interesting to note that in the chromosome region 1.1, the microsatellite locus Ap243 and the honey bee microRNA (ame-miR-2b) are located. As shown, host microRNAs respond to infection by the parasite $N$. ceranae [36]. In honey bees, 17 miRNAs were differentially expressed during N. ceranae infection, which may target over 400 predicted genes for ion binding, signaling, the nucleus, transmembrane transport and DNA binding. MicroRNA ame-miR-2b is particularly interesting because 11 out of 27 enzymes were significantly correlated with its expression level [36]. In addition, in the same region on chromosome 1, a suggestive QTL associated with the performance of Varroa sensitive hygiene was identified [21]. This locus contains more than candidate 30 genes [21], including puromycin-sensitive aminopeptidase involved in proteolytic events essential for cell growth and viability [83], selenoprotein F located in the endoplasmic reticulum and regulated by cell stress conditions [84], transcription and splicing factors and other genes. Since Microsporidian Nosema species are intracellular parasite [37], of particular interest is the cell wall integrity and stress response component 1. In Schizosaccharomyces pombe, the homologous gene $w s c 1$ is responsible for such biological processes as a cell surface receptor signaling pathway, intracellular signal transduction and regulation of cell wall organization or biogenesis [85].

Despite the fact that numerous QTLs associated with the disease resistance of honey bee have been identified, it is assumed that the variations in this trait is controlled by a small number of loci. For example, a strong genetic component is involved in the control of hygienic behavior, although it may also be influenced by environmental factors to some extent [14]. Therefore, the identification of the gene variants that are responsible for disease resistance in honey bees, and then breeding resistant bee colonies is one promising approach in the fight against bee disease.

\section{Conclusions}

The present study examined the associations between several variants of microsatellite loci and Nosema disease. In the dark forest bee, genetic markers promising for the assessment of nosemosis resistance, such as the allele "177" of the locus AC117, the allele "263" of the locus Ap243, the allele "269" of the locus SV185 have been identified. At the same time, some issues, for example, differences in the spectrum of loci and/or alleles that determine resistance to nosemosis in different bee subspecies/breeds, remained unresolved. In this regard, additional research both for the same bee subspecies/breeds bred in other regions, and for other bee subspecies/breeds is needed. However, already at this stage, these markers can be used to predict the risk of developing nosemosis, but with the obligatory consideration of the specificity of diagnostic markers for different bee subspecies/breeds.

Funding: This research received no external funding.

Institutional Review Board Statement: Not applicable.

Informed Consent Statement: Not applicable. 
Data Availability Statement: Data is contained within the article or Supplementary Material. The data presented in this study are available in [Ostroverkhova, N.V.; Kucher, A.N.; Konusova, O.L.; Kireeva, T.N.; Rosseykina, S.A.; Yartsev, V.V.; Pogorelov, Y.L. Genetic diversity of honey bee Apis mellifera in Siberia. In Phylogenetics of Bees; Ilyasov, R.A., Kwon, H.W., Eds.; CRC Press: Boca Raton, FL, USA, 2020; pp. 97-126 and Ostroverkhova, N.V.; Kucher, A.N.; Konusova, O.L.; Gushchina, E.S. Yartsev, V.V.; Pogorelov, Y.L. Dark-Colored Forest Bee Apis mellifera in Siberia, Russia: Current State and Conservation of Populations. In Selected Studies in Biodiversity; IntechOpen: London, UK, 2018; pp. 157-180].

Acknowledgments: The work would have been impossible without the help and assistance of Tatyana N. Kireeva, a researcher of the Tomsk State University.

Conflicts of Interest: The author declares no conflict of interest.

\section{References}

1. Chauzat, M.P.; Jacques, A.; Laurent, M.; Bougeard, S.; Hendrikx, P.; Ribière-Chabert, M.; EPILOBEE Consortium. Risk indi-cators affecting honey bee colony survival in Europe: One year of surveillance. Apidologie 2016, 47, 348-378. [CrossRef]

2. Vanengelsdorp, D.; Meixner, M.D. A historical review of managed honey bee populations in Europe and the United States and the factors that may affect them. J. Invertebr. Pathol. 2010, 103, S80-S95. [CrossRef] [PubMed]

3. Gomes, T.; Feás, X.; Iglesias, A.; Estevinho, L.M. Study of Organic Honey from the Northeast of Portugal. Molecules 2011, 16, 5374-5386. [CrossRef] [PubMed]

4. Higes, M.; Meana, A.; Bartolomé, C.; Botías, C.; Martín-Hernández, R. Nosema ceranae (Microsporidia), a controversial 21st century honey bee pathogen: N. ceranae an emergent pathogen for beekeeping. Environ. Microbiol. Rep. 2013, 5, 17-29. [CrossRef] [PubMed]

5. Goulson, D.; Nicholls, E.; Botías, C.; Rotheray, E.L. Bee declines driven by combined stress from parasites, pesticides, and lack of flowers. Science 2015, 347, 1255957. [CrossRef] [PubMed]

6. Bilodeau, L.; Sylvester, A.; Danka, R.; Rinderer, T. Comparison of microsatellite DNA diversity among commercial queen breeder stocks of Italian honey bees in the United States and Italy. J. Apic. Res. 2008, 47, 93-98. [CrossRef]

7. Bilodeau, L.; Rinderer, T.E.; Sylvester, H.A.; Holloway, B.; Oldroyd, B.P. Patterns of Apis mellifera infestation by Nosema ceranae support the parasite hypothesis for the evolution of extreme polyandry in eusocial insects. Apidologie 2012, 43, 539-548. [CrossRef]

8. Bilodeau, L.; Villa, J.D.; Holloway, B.; Danka, R.G.; Rinderer, T.E. Molecular genetic analysis of tracheal mite resistance in honey bees. J. Apic. Res. 2015, 54, 1-7. [CrossRef]

9. Büchler, R.; Berg, S.; Le Conte, Y. Breeding for resistance to Varroa destructor in Europe. Apidologie 2010, 41, 393-408. [CrossRef]

10. Spötter, A.; Gupta, P.; Nürnberg, G.; Reinsch, N.; Bienefeld, K. Development of a 44K SNP assay focussing on the analysis of a Varroa-specific defence behaviour in honey bees (Apis mellifera carnica). Mol. Ecol. Resour. 2011, 12, 323-332. [CrossRef]

11. Bixby, M.; Baylis, K.; Hoover, S.E.; Currie, R.W.; Melathopoulos, A.P.; Pernal, S.F.; Foster, L.J.; Guarna, M.M. A Bio-Economic Case Study of Canadian Honey Bee (Hymenoptera: Apidae) Colonies: Marker-Assisted Selection (MAS) in Queen Breeding Affects Beekeeper Profits. J. Econ. Èntomol. 2017, 110, 816-825. [CrossRef] [PubMed]

12. Yunusbaev, U.B.; Kaskinova, M.D.; Ilyasov, R.A.; Gaifullina, L.R.; Saltykova, E.S.; Nikolenko, A.G. The Role of Whole-Genome Studies in the Investigation of Honey Bee Biology. Russ. J. Genet. 2019, 55, 815-824. [CrossRef]

13. Maucourt, S.; Fortin, F.; Robert, C.; Giovenazzo, P. Genetic parameters of honey bee colonies traits in a Canadian Selection Program. Insects 2020, 11, 587. [CrossRef] [PubMed]

14. Spötter, A.; Gupta, P.; Mayer, M.; Reinsch, N.; Bienefeld, K. Genome-Wide Association Study of a Varroa-Specific Defense Behavior in Honeybees (Apis mellifera). J. Hered. 2016, 107, 220-227. [CrossRef] [PubMed]

15. Broeckx, B.J.G.; De Smet, L.; Blacquière, T.; Maebe, K.; Khalenkow, M.; Van Poucke, M.; Dahle, B.; Neumann, P.; Nguyen, K.B.; Smagghe, G.; et al. Honey bee predisposition of resistance to ubiquitous mite infestations. Sci. Rep. 2019, 9, 7794. [CrossRef]

16. Graham, A.M.; Munday, M.D.; Kaftanoglu, O.; Page, R.E., Jr.; Amdam, G.V.; Rueppell, O. Support for the reproductive ground plan hypothesis of social evolution and major QTL for ovary traits of Africanized worker honey bees (Apis mellifera L.). BMC Evol. Biol. 2011, 11, 95. [CrossRef]

17. Rueppell, O.; Metheny, J.D.; Linksvayer, T.; Fondrk, M.K.; Page, R.E., Jr.; Amdam, G.V. Genetic architecture of ovary size and asymmetry in European honeybee workers. Heredity 2011, 106, 894-903. [CrossRef]

18. Holloway, B.; Sylvester, H.A.; Bourgeois, L.; Rinderer, T.E. Association of single nucleotide polymorphisms to resistance to chalkbrood in Apis mellifera. J. Apic. Res. 2012, 51, 154-163. [CrossRef]

19. Holloway, B.; Tarver, M.R.; Rinderer, T.E. Fine mapping identifies significantly associating markers for resistance to the honey bee brood fungal disease, Chalkbrood. J. Apic. Res. 2013, 52, 134-140. [CrossRef]

20. Behrens, D.; Huang, Q.; Geßner, C.; Rosenkranz, P.; Frey, E.; Locke, B.; Moritz, R.F.A.; Kraus, F.B. Three QTL in the honey bee Apis mellifera L. suppress reproduction of the parasitic mite Varroa destructor. Ecol. Evol. 2011, 1, 451-458. [CrossRef]

21. Tsuruda, J.M.; Harris, J.W.; Bourgeois, L.; Danka, R.G.; Hunt, G.J. High-Resolution Linkage Analyses to Identify Genes That Influence Varroa Sensitive Hygiene Behavior in Honey Bees. PLoS ONE 2012, 7, e48276. [CrossRef]

22. Lapidge, K.L.; Oldroyd, B.P.; Spivak, M. Seven suggestive quantitative trait loci influence hygienic behavior of honey bees. Naturwissenschaften 2002, 89, 565-568. [CrossRef] [PubMed] 
23. Rüppell, O.; Pankiw, T.; Page, R.E., Jr. Pleiotropy, epistasis and new QTL: The genetic architecture of honey bee foraging behavior. J. Hered. 2004, 95, 481-491. [CrossRef] [PubMed]

24. Shorter, J.R.; Arechavaleta-Velasco, M.; Robles-Rios, C.; Hunt, G.J. A Genetic Analysis of the Stinging and Guarding Behaviors of the Honey Bee. Behav. Genet. 2012, 42, 663-674. [CrossRef] [PubMed]

25. Wilson-Rich, N.; Spivak, M.; Fefferman, N.H.; Starks, P.T. Genetic, individual, and group facilitation of disease resistance in insect societies. Annu. Rev. Entomol. 2007, 54, 405-423. [CrossRef] [PubMed]

26. Locke, B.; Forsgren, E.; De Miranda, J.R. Increased tolerance and resistance to virus infections: A possible factor in the survival of Varroa destructor resistant honey bees (Apis mellifera). PLoS ONE 2014, 9, e99998. [CrossRef] [PubMed]

27. Al Toufailia, H.; Evison, S.E.F.; Hughes, W.O.H.; Ratnieks, F.L.W. Both hygienic and non-hygienic honeybee, Apis mellifera, colonies remove dead and diseased larvae from open brood cells. Philos. Trans. R. Soc. B Biol. Sci. 2018, 373, 20170201. [CrossRef]

28. Rosenkranz, P.; Aumeier, P.; Ziegelmann, B. Biology and control of Varroa destructor. J. Invertebr. Pathol. 2010, 103, S96-S119. [CrossRef]

29. Nazzi, F.; Brown, S.P.; Annoscia, D.; Del Piccolo, F.; Di Prisco, G.; Varricchio, P.; Della Vedova, G.; Cattonaro, F.; Caprio, E.; Pennacchio, F. Synergistic parasite-pathogen interactions mediated by host immunity can drive the collapse of honeybee colonies. PLoS Pathog. 2012, 8, e1002735. [CrossRef]

30. Wagoner, K.M.; Spivak, M.; Rueppell, O. Brood Affects Hygienic Behavior in the Honey Bee (Hymenoptera: Apidae). J. Econ. Èntomol. 2018, 111, 2520-2530. [CrossRef]

31. Oxley, P.R.; Spivak, M.; Oldroyd, B.P. Six quantitative trait loci influence task thresholds for hygienic behaviour in honeybees (Apis mellifera). Mol. Ecol. 2010, 19, 1452-1461. [CrossRef] [PubMed]

32. Higes, M.; Martín-Hernández, R.; Garrido-Bailon, E.; Gonzalez-Porto, A.V.; Garcia-Palencia, P.; Meana, A.; Del Nozal, M.J.; Mayo, R.; Bernal, J.L. Honeybee colony collapse due to Nosema ceranae in professional apiaries. Environ. Microbiol. Rep. 2009, 1, 110-113. [CrossRef] [PubMed]

33. Vanengelsdorp, D.; Evans, J.D.; Saegerman, C.; Mullin, C.; Haubruge, E.; Nguyen, B.K.; Frazier, M.; Frazier, J.; Cox-Foster, D.; Chen, Y.; et al. Colony Collapse Disorder: A Descriptive Study. PLoS ONE 2009, 4, e6481. [CrossRef] [PubMed]

34. Goblirsch, M. Nosema ceranae disease of the honey bee (Apis mellifera). Apidologie 2017, 49, 131-150. [CrossRef]

35. Huang, Q.; Kryger, P.; Le Conte, Y.; Lattorff, H.M.G.; Kraus, F.B.; Moritz, R.F.A.; Lattorff, M. Four quantitative trait loci associated with low Nosema ceranae (Microsporidia) spore load in the honeybee Apis mellifera. Apidologie 2013, 45, 248-256. [CrossRef]

36. Huang, Q.; Chen, Y.; Wang, R.W.; Schwarz, R.S.; Evans, J.D. Honey bee microRNAs respond to infection by the microsporidian parasite Nosema ceranae. Sci. Rep. 2015, 5, 17494. [CrossRef]

37. Fries, I. Nosema apis-A Parasite in the Honey Bee Colony. Bee World 1993, 74, 5-19. [CrossRef]

38. Higes, M.; Martín, R.; Meana, A. Nosema ceranae, a new microsporidian parasite in honeybees in Europe. J. Invertebr. Pathol. 2006, 92, 93-95. [CrossRef]

39. Fries, I.; Chauzat, M.-P.; Chen, Y.P.; Doublet, V.; Genersch, E.; Gisder, S.; Higes, M.; McMahon, D.P.; Martín-Hernández, R.; Natsopoulou, M.; et al. Standard methods for Nosema research. J. Apic. Res. 2013, 52, 1-28. [CrossRef]

40. Zander, E. Tierische Parasiten als Krankheitserreger bei der Biene. Münchener Bienenztg. 1909, 31, $196-204$.

41. Klee, J.; Besana, A.M.; Genersch, E.; Gisder, S.; Nanetti, A.; Tam, D.Q.; Chinh, T.X.; Puerta, F.; Ruz, J.M.; Kryger, P.; et al. Widespread dispersal of the microsporidian Nosema ceranae, an emergent pathogen of the western honey bee, Apis mellifera. J. Invertebr. Pathol. 2007, 96, 1-10. [CrossRef] [PubMed]

42. Martín-Hernández, R.; Meana, A.; Prieto, L.; Salvador, A.M.; Garrido-Bailoón, E.; Higes, M. Outcome of Colonization of Apis mellifera by Nosema ceranae. Appl. Environ. Microbiol. 2007, 73, 6331-6338. [CrossRef] [PubMed]

43. Chen, Y.; Evans, J.D.; Smith, I.B.; Pettis, J.S. Nosema ceranae is a long-present and wide-spread microsporidian infection of the European honey bee (Apis mellifera) in the United States. J. Invertebr. Pathol. 2008, 97, 186-188. [CrossRef] [PubMed]

44. Fries, I.; Feng, F.; Da Silva, A.; Slemenda, S.B.; Pieniazek, N.J. Nosema ceranae n. sp. (Microspora, Nosematidae), morphological and molecular characterization of a microsporidian parasite of the Asian honey bee Apis cerana (Hymenoptera, Apidae). Eur. J. Protistol. 1996, 32, 356-365. [CrossRef]

45. Fries, I.; Martin, R.; Meana, A.; García-Palencia, P.; Higes, M. Natural infections of Nosema ceranae in European honey bees. J. Apic. Res. 2006, 47, 230-233. [CrossRef]

46. Fries, I. Nosema ceranae in European honey bees (Apis mellifera). J. Invertebr. Pathol. 2010, 103, S73-S79. [CrossRef]

47. Williams, G.R.; Shafer, A.B.; Rogers, R.E.; Shutler, D.; Stewart, D.T. First detection of Nosema ceranae, a microsporidian parasite of European honey bees (Apis mellifera), in Canada and central USA. J. Invertebr. Pathol. 2008, 97, 189-192. [CrossRef]

48. Giersch, T.; Berg, T.; Galea, F.; Hornitzky, M. Nosema ceranae infects honey bees (Apis mellifera) and contaminates honey in Australia. Apidologie 2009, 40, 117-123. [CrossRef]

49. Chen, Y.P.; Huang, Z.Y. Nosema ceranae, a newly identified pathogen of Apis mellifera in the USA and Asia. Apidologie 2010, 41, 364-374. [CrossRef]

50. Gisder, S.; Schüler, V.; Horchler, L.L.; Groth, D.; Genersch, E. Long-term temporal trends of Nosema spp. infection prevalence in northeast Germany: Continuous spread of Nosema ceranae, an emerging pathogen of honey bees (Apis mellifera), but no general replacement of Nosema apis. Front. Cell. Infect. Microbiol. 2017, 7, 301. [CrossRef]

51. Ostroverkhova, N.; Kucher, A.; Golubeva, E.; Rosseykina, S.; Konusova, O. Study of Nosema spp. in the Tomsk region, Siberia: Co-infection is widespread in honeybee colonies. Far East. Ėntomol. 2019, 378, 12-22. [CrossRef] 
52. Ostroverkhova, N.V. Prevalence of Nosema ceranae (Microsporidia) in the Apis mellifera mellifera bee colonies from long time isolated apiaries of Siberia. Far East. Èntomol. 2020, 407, 8-20. [CrossRef]

53. Ostroverkhova, N.V.; Konusova, O.L.; Kucher, A.N.; Sharakhov, I.V. A comprehensive characterization of the honeybees in Siberia (Russia). In Beekeeping and Bee Conservation-Advances in Research; Chambo, D.E., Ed.; InTech: Rijeka, Croatia, 2016 ; pp. 1-37.

54. Ostroverkhova, N.V.; Konusova, O.L.; Kucher, A.N.; Kireeva, T.N.; Rosseykina, S.A. Prevalence of the Microsporidian Nosema spp. in Honey Bee Populations (Apis mellifera) in Some Ecological Regions of North Asia. Vet. Sci. 2020, 7, 111. [CrossRef]

55. Higes, M.; Martín-Hernández, R.; Martínez-Salvador, A.; Garrido-Bailón, E.; González-Porto, A.V.; Meana, A.; Bernal, J.L.; Del Nozal, M.J. A preliminary study of the epidemiological factors related to honey bee colony loss in Spain. Environ. Microbiol. Rep. 2010, 2, 243-250. [CrossRef]

56. Bacandritsos, N.; Granato, A.; Budge, G.; Papanastasiou, I.; Roinioti, E.; Caldon, M.; Falcaro, C.; Gallina, A.; Mutinelli, F. Sudden deaths and colony population decline in Greek honey bee colonies. J. Invertebr. Pathol. 2010, 105, 335-340. [CrossRef]

57. Soroker, V.; Hetzroni, A.; Yakobson, B.; David, D.; David, A.; Voet, H.; Slabezki, Y.; Efrat, H.; Levski, S.; Kamer, Y.; et al. Evaluation of colony losses in Israel in relation to the incidence of pathogens and pests. Apidologie 2011, 42, 192-199. [CrossRef]

58. Martín-Hernández, R.; Bartolomé, C.; Chejanovsky, N.; Le Conte, Y.; Dalmon, A.; Dussaubat, C.; García-Palencia, P.; Meana, A.; Pinto, M.A.; Soroker, V.; et al. Nosema ceranae in Apis mellifera: A 12 years post-detection perspective. Environ. Microbiol. 2018, 20, 1302-1329. [CrossRef]

59. Traynor, K. Bee breeding around the world. Am. Bee J. 2008, 148, 135-139.

60. Huang, Q.; Kryger, P.; Le Conte, Y.; Moritz, R.F.A. Survival and immune response of drones of a Nosemosis tolerant honey bee strain towards N. ceranae infections. J. Invertebr. Pathol. 2012, 109, 297-302. [CrossRef]

61. Ellis, J. Stocks of bees in the United State. Am. Bee J. 2015, 1, 141-148.

62. Masterman, R.; Ross, R.; Mesce, K.; Spivak, M. Olfactory and behavioral response thresholds to odors of diseased brood differ between hygienic and non-hygienic honey bees (Apis mellifera L.). J. Comp. Physiol. A 2001, 187, 441-452.

63. Gerdts, J.; Dewar, R.L.; Simone-Finstrom, M.D.; Edwards, T.; Angove, M. Hygienic behaviour selection via freeze-killed honey bee brood not associated with chalkbrood resistance in eastern Australia. PLoS ONE 2018, 13, e0203969. [CrossRef]

64. Leclercq, G.; Francis, F.; Gengler, N.; Blacquière, T. Bioassays to Quantify Hygienic Behavior in Honey Bee (Apis mellifera L.) Colonies: A Review. J. Apic. Res. 2018, 57, 663-673. [CrossRef]

65. Guichard, M.; Neuditschko, M.; Soland, G.; Fried, P.; Grandjean, M.; Gerster, S.; Dainat, B.; Bijma, P.; Brascamp, E.W. Estimates of genetic parameters for production, behaviour, and health traits in two Swiss honey bee populations. Apidologie 2020, 1-16. [CrossRef]

66. Rothenbuhler, W.C. Behavior genetics of nest cleaning in honey bees. IV. Responses of F1 and backcross generations to diseasekilled brood. Am. Zool. 1964, 4, 111-123. [CrossRef]

67. Gilliam, M.; Taber, S.; Richardson, G.V. Hygienic behavior of honey bees in relation to chalk brood disease. Apidologie 1983, 14, 29-39. [CrossRef]

68. Spivak, M.; Gilliam, M. Facultative expression of hygienic behavior of honey bees in relation to disease resistance. J. Apic. Res. 1993, 32, 147-157. [CrossRef]

69. Arechavaleta-Velasco, M.E.; Guzman-Novoa, E. Relative effect of four characteristics that restrain the population growth of the mite Varroa destructor in honey bee (Apis mellifera) colonies. Apidologie 2001, 32, 157-174. [CrossRef]

70. Ibrahim, A.; Spivak, M. The relationship between hygienic behavior and suppression of mite reproduction as honey bee (Apis mellifera) mechanisms of resistance to Varroa destructor. Apidologie 2005, 37, 31-40. [CrossRef]

71. Locke, B. Natural Varroa mite-surviving Apis mellifera honeybee populations. Apidologie 2016, 47, 467-482. [CrossRef]

72. Valizadeh, P.; Guzman-Novoa, E.; Goodwin, P.H. Effect of Immune Inducers on Nosema ceranae Multiplication and Their Impact on Honey Bee (Apis mellifera L.) Survivorship and Behaviors. Insects 2020, 11, 572. [CrossRef] [PubMed]

73. Ostroverkhova, N.V.; Kucher, A.N.; Konusova, O.L.; Kireeva, T.N.; Rosseykina, S.A.; Yartsev, V.V.; Pogorelov, Y.L. Genetic diversity of honey bee Apis mellifera in Siberia. In Phylogenetics of Bees; Ilyasov, R.A., Kwon, H.W., Eds.; CRC Press: Boca Raton, FL, USA, 2020; pp. 97-126.

74. Ostroverkhova, N.V.; Kucher, A.N.; Konusova, O.L.; Gushchina, E.S.; Yartsev, V.V.; Pogorelov, Y.L. Dark-colored forest bee Apis mellifera in Siberia, Russia: Current state and conservation of populations. In Selected Studies in Biodiversity; IntechOpen: London, UK, 2018; pp. 157-180.

75. Solignac, M.; Vautrin, D.; Loiseau, A.; Mougel, F.; Baudry, E. Five hundred and fifty microsatellite markers for the study of the honey bee (Apis mellifera L.) genome. Mol. Ecol. Notes 2003, 3, 307-311. [CrossRef]

76. Raymond, M.; Rousset, F. GENEPOP (Version 1.2): Population Genetics Software for Exact Tests and Ecumenicism. J. Hered. 1995, 86, 248-249. [CrossRef]

77. Morris, J.A.; Gardner, M.J. Statistics in Medicine: Calculating confidence intervals for relative risks (odds ratios) and standardised ratios and rates. BMJ 1988, 296, 1313-1316. [CrossRef]

78. Ostroverkhova, N.V.; Kireeva, T.N. Genetic diversity of Apis mellifera carpathica honey bee subspecies. Far East. Èntomol.. In Preparation.

79. Muli, E.; Patch, H.; Frazier, M.; Frazier, J.; Torto, B.; Baumgarten, T.; Kilonzo, J.; Kimani, J.N.; Mumoki, F.; Masiga, D.; et al. Evaluation of the Distribution and Impacts of Parasites, Pathogens, and Pesticides on Honey Bee (Apis mellifera) Populations in East Africa. PLoS ONE 2014, 9, e94459. [CrossRef] 
80. Fleming, J.C.; Schmehl, D.R.; Ellis, J.D. Characterizing the Impact of Commercial Pollen Substitute Diets on the Level of Nosema spp. in Honey Bees (Apis mellifera L.). PLoS ONE 2015, 10, e0132014. [CrossRef]

81. Azzouz-Olden, F.; Hunt, A.G.; DeGrandi-Hoffman, G. Transcriptional response of honey bee (Apis mellifera) to differential nutritional status and Nosema infection. BMC Genom. 2018, 19, 628. [CrossRef]

82. Mendoza, Y.; Tomasco, I.; Antúnez, K.; Castelli, L.; Branchiccela, B.; Santos, E.; Invernizzi, C. Unraveling Honey Bee-Varroa destructor Interaction: Multiple Factors Involved in Differential Resistance between Two Uruguayan Populations. Vet. Sci. 2020, 7, 116. [CrossRef]

83. Bhutani, N.; Venkatraman, P.; Goldberg, A.L. Puromycin-sensitive aminopeptidase is the major peptidase responsible for digesting polyglutamine sequences released by proteasomes during protein degradation. EMBO J. 2007, 26, 1385-1396. [CrossRef]

84. Ren, B.; Liu, M.; Ni, J.; Tian, J. Role of Selenoprotein F in Protein Folding and Secretion: Potential Involvement in Human Disease. Nutrients 2018, 10, 1619. [CrossRef] [PubMed]

85. Davì, V.; Tanimoto, H.; Ershov, D.; Haupt, A.; De Belly, H.; Le Borgne, R.; Couturier, E.; Boudaoud, A.; Minc, N. Mechanosensation dynamically coordinates polar growth and cell wall assembly to promote cell survival. Dev. Cell 2018, 45, 170-182. [CrossRef] [PubMed] 